\title{
GLOBALIZATION AND THE PROVISION OF INCENTIVES INSIDE THE FIRM: The Effect of Foreign Competition
}

\author{
Vicente Cuñat \\ Universitat Pompeu Fabra
}

\author{
Maria Guadalupe* \\ Columbia University and CEPR
}

This Draft: October 2006

\begin{abstract}
This paper studies the effect of changes in foreign competition on the incentives faced by U.S. managers in the form of wage structures, promotion profiles, and job turnover. We use a panel of executives and measure foreign competition as import penetration. Using tariffs and exchange rates as instrumental variables, we estimate the causal effect of globalization on the labor market outcomes of these workers. We find that higher foreign competition leads to more incentive provision in a variety of ways. First, it increases the sensitivity of pay to performance. Second, it raises the return to a promotion and increases pay inequality among the top executives of the firm, with CEOs typically experiencing wage increases while lower-ranking executives see their wages fall. Third, higher competition is associated with a higher probability of leaving the firm. Finally, we show that higher foreign competition also is associated with a higher demand for talent at the top of the firm. These results indicate that increased foreign competition can explain some of the recent trends in compensation structures.
\end{abstract}

JEL codes: M52, L1, J31

Keywords: Incentives; Performance-related-pay; Wage Structure; Wage Ladders; Job Turnover; Promotions; Demand for talent; Foreign Competition; Globalization; Product Market Competition.

${ }^{*}$ We would like to thank Luca Stanca, John Van Reenen and an anonymous referee of the CAFE conference for their insightful comments and suggestions as well as seminar participants at Columbia University, Wharton, the SOLE 2006 meetings, the NBER Summer Institute, CAFE conference, Universidad Carlos III, EUI, MILLS Workshop and UPF. Corresponding author: Maria Guadalupe, a: 3022 Broadway, Uris Hall 624, New York NY 10025; p: 212854 6176; e: mg2341@columbia.edu 


\section{Introduction}

The structure of wages and compensation in the United States changed substantially over the 1980s and 1990s. Firms increased their use of performance-related pay, such as piece rates, bonuses, and stock options, to provide incentives. Simultaneously, earnings inequality, returns to skill, and compensation at the top of the distribution increased substantially; job mobility was also higher, although only for certain groups of workers. These changes affected executives at the top of the earnings distribution along with workers in general. ${ }^{1}$ In spite of the extensive literature on changes in inequality and job mobility, and the discussions on why there has been an increase in CEO pay, little is known about the reasons for the dramatic changes in compensation structures and incentive provision. What are the driving forces behind these trends? ${ }^{2}$

In this paper, we argue that a major force behind many of these changes is the increase in foreign competition resulting from reductions in trade barriers and the globalization of economic activity. Foreign competition, and globalization more generally, can have an impact on incentive structures to the extent that they make product markets more competitive (Tybout, 2003). Higher imports, changes in entry barriers, lower costs of transport, and information diffusion all tend to increase the degree of competition that firms face; therefore, they should indirectly affect the provision of incentives by firms (Hermalin, 1992; Schmidt, 1997; Raith, 2004). We proceed here with an empirical assessment of the extent to which changes in foreign competition, measured as the degree of import penetration faced by U.S. firms from 1992 to 2000, affected how they provided incentives.

The variation in import competition over time and across industries allows us to clearly identify one of the channels through which globalization affects the working of firms. We

\footnotetext{
${ }^{1}$ Murphy (1999) surveys the evidence on the increase in total pay and performance-pay sensitivities for executives. Lemieux et al. (2005) show that the use of bonus and incentive contracts increased in the United States not only for executives but also for workers. Frydman (2005) provides further evidence of the evolution of pay and finds that inequality among executives increased, CEO pay went up, and job mobility was higher in the 1980s and 1990s than in earlier decades. Katz and Autor (1999) survey the evidence on changes in inequality and returns to skill.

${ }^{2}$ Murphy and Zabojnik (2004 a and b) and Frydman (2005) claim that the increase in CEO pay is due to higher demand for general skills. Similarly, Gabaix and Landier (2006) argue that the existence of bigger and more integrated firms has increased the impact of CEO skills and therefore boosted their compensation. Competition can be thought of as an additional explanation that also could explain why the demand for general skills may have increased. Bebchuk and Fried (2005) argue that it is due to an increase in rent extraction on the part of managers, camouflaged as incentive provision, although reason why the incentives to extract rents from the firm have changed is unclear.
} 
assess how firms in different industries, with different evolutions in their trade exposure, changed their incentive structures during the 1990s in the U.S. ${ }^{3}$ In addition to showing the overall effect, and in order to isolate fluctuations in foreign competition that are exogenous to the incentive policies of firms and uncorrelated with potential omitted variables, we use import tariffs and exchange rates as instruments. ${ }^{4}$ Tariffs and exchange rates provide a compelling source of variation, because their evolution differs across sectors throughout the study period, and they are arguably exogenous to current executive employment. The use of instrumental variables allows us to provide a precise causal effect, that is possibly a lower bound for the overall effect of the changes in competition.

While we restrict the impact of globalization to its effect via import penetration, we try to be as comprehensive as possible in the definition of incentives. Incentives to exert effort and to improve the manager's total contribution to the productivity of the firm can be provided in several ways. Some are explicit and contractual such as agreeing on a bonus or a performance-related pay scheme. Others are implicit (without an explicit written contract) and enforced on the basis of commitment and reputation. These include discretionary bonuses or the commitment of the firm to a given promotion scheme. Finally, some incentives may not be provided directly by firms but rather are implicit in labor market conditions (e.g. the good performance of one executive in a given firm may lead another firm to offer this same executive a better job). ${ }^{5}$ To provide a comprehensive view of the provision of incentives inside firms, we relate changes in foreign competition to a number of measures; the incentives may be provided through explicit contracts or implicit agreements, through direct rewards on contemporaneous performance or indirect ones based on promotions, and via turnover or career concerns in general.

Even though executives are only a subsample of the general employed population, they have some characteristics that make them an ideal study group for answering some of the questions we are interested in. First, the availability of data on executive compensation allows us to perform a detailed analysis of wages and promotions. We use a matched employer-employee panel dataset (Execucomp) with five executives per firm. It contains

\footnotetext{
${ }^{3}$ We are able to compute the level of import penetration faced by the firm itself by taking into account the fact that it may have products in different four-digit SIC industries.

${ }^{4}$ Exchange rates (import tariffs) are weighted by the relative importance of each currency (trading partner) in total industry imports, so that there is differential variation across industries in a given period. We then construct firm-specific measures, according to the industries in which the firm operates.

${ }^{5}$ See Gibbons (2005) and Gibbons and Waldman (1999) for a broad survey of theoretical and empirical results on the different channels for incentive provision.
} 
very detailed information on both firm and employment characteristics, providing a fairly comprehensive picture of internal labor markets and incentive provision. One can track executives as the extent of foreign competition faced by the firm evolves, and evaluate how incentives change over time and across industries. The richness of the data allows us to look at a variety of measures that capture incentives, including: 1) fixed and variable pay; 2) within-firm wage inequality and promotion ladders; and 3) turnover. We are also able to assess whether firms seek to hire more "able" or "talented" CEOs and executives as foreign competition changes. These measures taken together give us a comprehensive view of the provision of incentives.

Second, this particular group of workers allows us to better identify the effect of changes in foreign competition on firm contracting behavior, independent of its effects on labor markets. This is because the boundaries of labor and product markets are relatively independent when it comes to executives, who more frequently change firms between industries rather than within industries. ${ }^{6}$ Moreover, collective bargaining is virtually non-existent among executives. Therefore, it is unlikely that individual executives internalize the effect of their joint compensation packages on firm profits. Thus, by concentrating on executives, we are able to isolate the effects that come mostly from product market competition. ${ }^{7}$

Finally, even though executives constitute a very specific subset of highly skilled workers, comparing our results on executives with existing results on the general labor force may shed some light on how foreign competition affects high- versus and low-skilled workers.

Our results show that higher foreign competition reduces the level of fixed pay and increases the sensitivity of pay to performance. At the same time, it increases the steepness of the promotion ladder and pay inequality within a firm. Higher competition also is associated with higher job turnover, although the causality of this last result is less clear. All of these results suggest that with more competition, firms provide more incentives to executives. Finally, we assess whether the increase in job mobility is associated with firms hiring more "talented" managers. We identify "ability" or "talent" (the permanent unobserved component of wages) from the estimated individual fixed effects and find that, as foreign competition increases, firms hire more "talented" CEOs.

This paper also contributes to the literature on the positive relationship between wage

\footnotetext{
${ }^{6}$ For example, $71 \%$ of the transitions of executives between firms included in Execucomp are between sectors when they are defined at a 4-digit SIC code level (64\% when defined at a 3-digit level).

${ }^{7}$ As a reference, the median compensation of an executive in Execucomp represents $0.1 \%$ of the median firm revenue.
} 
inequality and trade openness. We show that foreign competition may affect the provision of incentives within firms in two ways that raise inequality: by increasing wage dispersion within firms; and, through the use of performance-related pay. This is important because most of the mechanisms explored to link inequality and trade have failed to fully account for the overall positive correlation, including the effects of openness on total labor supply, total labor demand, skill-biased labor demand, and institutions (Slaughter, 1999). Here we suggest an additional mechanism. ${ }^{8}$

The rest of the paper is as follows: in Section 2, we present the general structure of the paper and the related literature; Section 3 presents the data used in the empirical sections; Section 4.1 shows the specification and the results relative to fixed and variable pay; Section 4.2 presents the results on promotion ladders and turnover; Section 4.4 explores how firms reward talent differently according to the degree of foreign competition; and Section 5 provides an overall picture and concludes.

\section{Background and Related Literature}

The growth of foreign competition, and globalization more generally, implies that firms are increasingly exposed to competitive pressure. An increase in import penetration in an industry means that domestic firms are facing more competition because foreign firms have a bigger presence in the market. Furthermore, changes in foreign competition can permanently reshape the general competitive configuration of an industry; that is, if there are some fixed entry costs, once foreign firms decide to enter the market, they are unlikely to exit. ${ }^{9}$ Therefore, one can think of the increase in foreign competition as an increase in competitive pressure for the industry.

The effect of competition on incentive provision within the principal-agent framework has been studied in a number of papers (Schmidt, 1997; Raith, 2003; Vives, 2004). A general result of virtually all competition models is that, with more competition, the residual demand that a firm faces becomes more elastic and shifts down. ${ }^{10}$ This generates two counteracting effects in terms of incentives: on the one hand, more competition raises the reward to market stealing activities due to the additional elasticity of substitution.

\footnotetext{
${ }^{8}$ Lemieux et al (2005) empirically establish the link between the growing use of performance-related pay and the increase in wage inequality in the U.S. between the 1970s and 1990s.

${ }^{9}$ See Baldwin (1988), Dixit (1989) and Baldwin and Krugman (1989)

${ }^{10}$ See Vives (2004) and Boone (2000) for an overview on these two effects.
} 
This implies a higher marginal return to managerial and workers' effort that leads firms to introduce steeper incentive packages. On the other hand, the residual demand that a firm faces shrinks, shifting the profit function downwards, and making market stealing less attractive. This leads the firm to reduce the steepness of its incentive contracts. ${ }^{11}$ Overall, the total effect of competition on incentive pay is theoretically ambiguous, which makes this an interesting empirical question. ${ }^{12}$

One related effect is that executives face an implicit incentive when competition increases the risk of the firm going bankrupt. Schmidt (1997) explicitly models this incentive, and several empirical papers (Nickell, 1996; Galdon-Sanchez and Schmitz, 2002) show empirically that if additional competition leads to more pressure on profits, employees tend to work harder. If an increase in foreign competition indeed reduces profits, then this would implicitly discipline workers, thus reducing the need for the firm to provide explicit incentives.

An increase in competition also may increase the available information about market conditions and help firms to elicit the contribution of an executive to profits (Hart, 1983; Scharfstein, 1988; and Hermalin, 1992). This may lead to a change in the steepness of incentive schemes, and more generally to increased use of relative-performance evaluation. However, in this literature the overall predicted effect on the relationship between competition and incentives is also ambiguous.

Our analysis asks what is the net effect that dominates empirically for various ways in which firms provide incentives. We explicitly study the sensitivity of pay to performance (Section 4.1), the returns to a promotion in the firms' wage ladder (Section 4.2) and turnover probabilities (Section 4.4).

To the extent that firms can increase performance (cut marginal costs of production) either by increasing the effort exerted or by hiring a more skilled/talented manager, many of the arguments for rewarding managerial effort are also valid for rewarding skill (Guadalupe, 2004) and managerial talent. Marin and Verdier (2003) present a model in which globalization affects the hierarchical structure of the firm and the reward for talent. Firms change their hierarchical structure, and thus the explicit and implicit incentives that executives

\footnotetext{
${ }^{11}$ Raith (2003) allows for free entry and exit of firms so that firm profits are constant and his second effect is not present.

${ }^{12}$ Cuñat and Guadalupe (2004) and (2005) find evidence that competition, measured as deregulation in the U.S. financial services and a sharp appreciation in the U.K., respectively, raised performance-pay sensitivities.
} 
face, and increase their demand for talented CEOs. ${ }^{13}$ In this paper, we analyze the empirical effect of competition on both firm hierarchies (section 4.2) and the reward for talent (section 4.3).

The present paper is related to several others that associate foreign competition with various labor market outcomes. Revenga (1992) relates micro-data on unemployment and wages to import penetration at the sector level; she finds that increased foreign competition led to higher unemployment and lower wages over the 1977-1987 period. Bertrand (2004) shows that for the average U.S. worker, implicit contracts are replaced by spot contracting as competition increases. She analyzes how the relationship between wages and unemployment at the sector level is affected by import penetration. She finds that the more competitive the industry is, the more salaries are responsive to current rather than past unemployment rates.

In two related papers, Abowd and Lemieux (1992) and Abowd and Allain (1996) find that the elasticity of salaries to firms' quasi-rents increases when the latter are instrumented using shocks to foreign competition. The underlying idea behind these two articles is that foreign competition modifies the labor market conditions of an industry in that it alters the rents available to be split, the outside options of employees, and the bargaining power of the parties. ${ }^{14}$ Therefore, foreign competition affects bargaining conditions and labor market institutions. Our article departs from this perspective because, by concentrating on executives, labor market considerations and changes to labor market institutions are less likely to play a role, while issues related to product market competition and governance may be more relevant.

We also depart from the papers mentioned above because we study changes in the structure of compensation within firms (not just pay levels), changes in the structure of hierarchies, executive turnover, and the demand for talent. We also extend the identification strategy in Revenga (1992) and Bertrand (2004) by using tariffs as an additional instrument of import penetration and by calculating firm-specific import penetration, exchange rates, and tariffs. ${ }^{15}$

\footnotetext{
${ }^{13}$ The effects of competition and globalization on hierarchies are the subject of a growing literature (Antras et al., 2006; Rajan and Wulf, 2006).

${ }^{14}$ See also Kramarz (2006)

${ }^{15}$ An argument, related to ours, relative to globalization and pay can be found in Feenstra and Hanson (1997). They show that an increase in foreign direct investment increases the returns to skill in Mexican firms.
} 


\section{Data}

\subsection{Compensation Data}

We use the Standard\&Poor's Execucomp dataset. This is a panel (starting in 1992) of all firms in the S\&P 1500 index. ${ }^{16}$ Each firm reports detailed yearly information on the pay structure of the five most highly paid executives in the firm (ranked by salary and bonus) as well as some individual characteristics. The data also contain information from financial statements on firm characteristics and performance. For our purposes, one unique feature of this data is that it allows us to follow firms and executives over time, in a panel setting. We use yearly data from 1992 to 1999 for all manufacturing sectors. The data start in 1992, and 1999 is the last year for which we are able to compute import penetration. Manufacturing is the sector for which we have trade data. This leaves us with 737 firms and 6,325 executives (23,222 unique observations).

From this data, we obtain for each executive in the sample a comprehensive measure of total yearly compensation, including the components of pay that are related to performance and those that are not (in particular, we are able to include stock options and long-term incentive plans (Murphy, 1999)). This is the natural logarithm of the sum of salary, bonus, total value of stock options granted (valued using the standard Black-Scholes formula), total value of restricted stock granted, long-term incentive payouts and other annual compensation. ${ }^{17}$ We also define and use the logarithm of salary-plus-bonus.

\subsection{Discussion of Foreign Competition and its Instruments: Identification}

The data analysis in the next section evaluates the effect of foreign competition on firm $f$ in industry $j$ at time $t\left(i m p_{f j t}\right)$ on a number of aspects of compensation and incentives, for each individual $i$. We run regressions of the form:

$$
\ln \left(W_{i f j t}\right)=\alpha+\gamma_{1} i m p_{f j t}+i m p_{f j t} * X_{i f j t}^{\prime} \gamma_{2}+X_{i f j t}^{\prime} \gamma_{3}+z_{i f j t}^{\prime} \beta+u_{i f j t}
$$

where $W_{i f j t}$ is total compensation, $z_{i f j t}^{\prime}$ are control variables such as firm size or industry dummies. We evaluate the effect of import penetration $i m p_{f j t}$ and eventually its interaction

\footnotetext{
${ }^{16}$ The index includes firms in the S\&P 500, S\&P MidCap 400, and S\&P SmallCap 600 indices, so it represents a stratified sample of listed firms of all sizes.

${ }^{17}$ Execucomp variable TDC1.
} 
with some variables $X_{i f j t}{ }^{18}$ and allow for different specifications of the error term $u_{i f j t}$ (see each individual model below).

The measure of import penetration $i m p_{f j t}$ used in what follows is defined at the firm level, and takes into account that one firm may operate in different industries. To derive this firm-specific measure of import penetration, we first define industry-level import penetration (at 4-digit SIC) as imports divided by the total value of internal production plus imports. This measures the extent to which foreign competitors penetrate the local market. For each industry, we average the current and one-forward-lag import penetration, and take its deviation with respect to the industry mean. Taking the deviation and including industry dummies in all the regressions ensures that in $\widehat{\gamma_{1}}$ or $\widehat{\gamma_{2}}$ we do not capture unobserved differences by industry that are correlated with import penetration.

We exploit the variation in import penetration across industries. Over the sample period, average import penetration goes from 0.16 to 0.21 , but it increases for some sectors and decreases for others such that, in a given year, we may find a rich combination of changes for different sectors. As an example, Figure 1 shows this variation for three selected industries.

Since many firms sell goods in more than one industry, import penetration into the firm's main industry may be a misleading measure of the actual import penetration that the firm faces. To account for this, we define a firm-specific import penetration measure, $i m p_{f j t}$, as the weighted average of the industry-level import penetration (computed as above) that the firm faces in all of the industries in which it operates. The weights are constructed as the fraction of total sales associated with each SIC4 industry in which the firm operates (declared business segments from Compustat Segments data). Because the industries the firm operates in may change endogenously over time, the weights used correspond to the firm's operations in 1991. Here the identification arises from import penetration changing within a firm over time. The advantage of this choice is that it is immune to endogenous production decisions; the disadvantage is that, by the end of the sample (1999), and given the fixed 1991 weights, variations in this measure may not be highly correlated with the actual import penetration that the firm faces in a particular year. We ran all of the specifications using the industry-based measure, ${ }^{19}$ and our results were qualitatively very similar to the ones using the firm-based variable. Since the latter is a better measure of the degree of import competition the firm actually faces, and because it is not subject to endogenous

\footnotetext{
${ }^{18}$ These depend on the outcome of interest. It can be firm performance (Section 4.1) or hierarchical level (Sections 4.2 and 4.3).

${ }^{19}$ Where each firm is assigned the import penetration of its primary SIC4 code.
} 
changes of industry of operation, we only show the results using this measure. ${ }^{20}$

However rich the variation of import penetration is in the panel, its use still can be subject to a number of criticisms in terms of possible endogeneity problems. These problems either could be the result of reverse causality or omitted explanatory variables that affect both pay policies and import penetration. To deal with this, we use an instrumental variables approach that isolates the causal effect of import penetration by focusing on exogenous variation in imports.

One can think of a number of potential endogeneity problems in the non-instrumented regressions. For example, in terms of reverse causality, one could argue that changes in compensation structure may drive the behavior of executives and, therefore, the degree of competition in the market (Aggarwal and Samwick, 1999) and the extent to which foreign firms enter. This problem should be solved by using instruments that are correlated with import penetration and exogenous to the firm's pay policies.

Second, there may be omitted variables that are correlated with import penetration and not captured by the controls, such as exports or other dimensions of trade, variables related to rent-extraction, and general demand shocks. The endogeneity problems associated with exports or other trade variables might be important if we used aggregate imports as our explanatory variable. Using firm-specific import penetration and instruments instead deals with the correlation between imports and other trade variables (we discuss this further later in the paper).

The rent-extraction argument (Bebchuk and Fried, 2005; Bertrand and Mullainathan, 2001) says that the change in incentives can be driven by rent extraction, camouflaged in the variable component of pay, so that executives appear to get paid for luck. However, an increase in competition tends to increase transparency and lower the availability of rents (it is a "bad luck" shock in Bertrand and Mullainathan); we would therefore expect that the extent of rent extraction via camouflage is lower, but we find the opposite. If present, the rent-extraction mechanism actually would tend to reduce the size of our incentive-related coefficients, thus pushing our results downwards. A similar argument can be made with respect to demand shocks. A positive shock to domestic demand in a given sector would increase local production and imports and, at the same time, could affect the pay policies of the firms. However, the sign of this effect in terms of import penetration is unclear, and

\footnotetext{
${ }^{20}$ The results are not substantially different if we use "running" firm-specific weights (where the weights vary as the firm changes its product mix). However, since product mix is endogenous, we favor the fixedweight measure.
} 
likely to be sector-specific. Instrumental variables also address this concern.

Finally, it is possible that to some extent, import fluctuations are foreseen by firms and anticipated, so changes observed in a given year under-estimate the actual reaction. And import penetration indeed may be measured with error, thus leading to attenuation bias.

For all of the reasons listed above, the effect of import penetration on our measures of compensation and incentives might be underestimated, and therefore the results biased towards zero. To deal with these endogeneity concerns, and in order to evaluate the effect of purely exogenous fluctuations in import penetration, we provide instrumental variables results.

The first instrument used follows Bertrand (2004), who constructs a measure of industryspecific import-weighted exchange rates. The weights on the bilateral exchange rates between the U.S. and its trading partners are the average proportion in total imports from each country in the years 1990 and 1991. The weighted exchange rates are recalculated at the firm-level using the weights from the Compustat segments data, as we did with the import penetration measure. This instrument is arguably exogenous because exchange rates are determined in international financial markets and therefore are uncorrelated with firms' compensation policy. By choosing static weights, we avoid any possible endogeneity that could arise from the joint determination of the weights and exchange rates. We use both current and one-lag exchange rates.

Using firm-specific exchange rates has two important advantages. First, different currency mixes across industries and firms imply that, in any given year, one firm may be subject to an appreciation while another may be subject to a depreciation. This allows for richer variation in instrumented import penetration than if we were using a single exchange rate for all sectors. Second, using static import weights increases the explanatory power of exchange rates for imports and reduces their explanatory power for potential confounding factors, thus reinforcing the exclusion restriction. For example, import-weighted exchange rates are poorly related to exports, so our instrumented regressions are not capturing an indirect effect of exchange rates through changes in exports.

As a second instrument, we use import tariffs faced by firms wanting to enter the U.S. market. Tariff data come from the UNCTAD TRAINS dataset. We define the average tariff of a particular industry as the weighted average of tariffs set by the U.S. on imports from each country. To avoid endogeneity, the weights are the proportion of imports from each country measured in the dataset's base year (1993). Then we calculate the firm-specific 
tariff using segments data and use one-year lag of the tariff measure. Again, this is arguably exogenous because tariffs are determined either at trade negotiation rounds (WTO) or by federal policy, and thus independent of firm's compensation policies and incentives. Indeed, most of our tariff variation is around 1995, when the Uruguay round was implemented. It is also not obvious that there is a channel through which changes in tariffs facing foreign firms will affect the employment policy of domestic firms via something other than imports. Since tariff data is available only from 1993 onwards, and because we use lagged tariffs, our instrumented regressions effectively cover the period 1994-1999.

All of the tariff and trade information comes from the NBER database ${ }^{21}$ and the UNCTAD TRAINS dataset. Total production at the industry level comes from the Bureau of Economic Analysis Industry Shipments data. Further details of all the variables and their construction can be found in the appendix.

One implicit maintained assumption (the exclusion restriction) is that the instruments only have an effect on the dependent variable through import penetration. To evaluate this, we regress export openness (that is, exports over total production at 4-digit SIC, demeaned by industry) at the industry-level on our three instrumental variables in a regression that controls for year and industry dummies. We find that they have no explanatory power, which lends some support to the exclusion restriction (see Column 4 of Table 2).

For each of our specifications, we provide two-stage least-squares estimates of equation 1, where $i m p_{f j t}$ and $i m p_{f j t} * X_{i f j t}$ are instrumented with the source-weighted exchange rate (current and lagged), lagged tariffs for industry $j$ in year $t$, and the interaction of these terms with the relevant $X_{i f j t}$ variables (as in Bertrand, 2004).

Column 1 of Table 2 shows the basic first-stage underlying the paper; it regresses import penetration on current exchange rate, lagged exchange rate, and lagged tariffs. Import penetration and the instruments are defined by firm using the business segments weights. The effect of exchange rates and tariffs is highly significant. The results with respect to the exchange rate indicate that depreciation of the dollar by one standard deviation would lead to a $\mathbf{2}$ percentage point increase in import penetration after one-year lag; i.e. a full standard deviation (the contemporaneous effect is smaller, just half a percentage point). The effect of tariffs is smaller but highly significant and has the expected sign, with lower tariffs leading to increases in import penetration (one standard deviation increase in tariffs leads to a 0.8

\footnotetext{
21 "US Imports, Exports and Tariff Data, 1989-2001 (NBER 9387)". See Feenstra et al (2002) for a detailed description of the construction of each of these variables.
} 
percentage points fall in import penetration, or a fall of a third of a standard deviation). The joint significance of all the instruments and control variables is quite high, with an $\mathrm{R}^{2}$ around $30 \%$. Moreover, the additional $\mathrm{R}^{2}$ explained by the instrumental variables excluded in the second stage (exchange rate, lagged exchange rate, and lagged tariffs) is around $5 \%$. The test of the excluded instruments shows that their joint explanatory power is statistically significant. Because we have 3 instruments, we test for overidentification in all the regressions and cannot reject the null, that they are valid instruments (uncorrelated with the error and therefore excluded correctly from the regression). The second-stage results were similar if we only used tariffs or exchange rates; this lends further credibility to the instrumental variables. Columns 2 and 3 of Table 2 show the first stage of the first specification in the paper, which includes performance as one of the regressors, with similar results. Whenever imports is interacted with other variables $X_{i f j t}$ in a specification, that interaction is instrumented with the instruments and their interaction with $X_{i f j t}$ in a twostage least-squares setting, as in Bertrand (2004).

It is important to emphasize that even though globalization is a pervasive trend, the effect identified here is deliberately much narrower than the overall trend, so we can confidently say something about causality. To avoid capturing a spurious trend, we exploit the panel, where import penetration varies in different directions in different industries (and firms), and we include year and industry dummies in all the regressions. Furthermore, the instrumental variables results capture changes in the structure of compensation as a response to unexpected shocks - which by their nature are not spurious - to import penetration. Focusing on this narrow channel has the advantage that we know where the variation is coming from, and it provides a clear channel for the effect. The cost of this strategy is that globalization may operate through various other channels, and our results may be a lower bound of the overall effect of globalization on compensation structures.

\section{Results}

\subsection{Pay Structure}

Executive pay has a fixed component and a component that is related to performance. As mentioned earlier, in the 1980s and 1990s, the proportion of the variable component in total pay and the sensitivity of pay to performance increased. Here we assess the effect of foreign competition on this trend. 
Total compensation for each executive $i$ in firm $f$, in industry $j$, in year $t$, can be written as $\ln \left(W_{i f j t}\right)=A_{i f j t}+B_{i f j t}\left(\operatorname{Perf}_{f j t}\right)+\sum \delta_{s} X_{i f j t}^{s}+d_{t}+d_{j}+\eta_{i}+\epsilon_{i f j t}$. where $X_{i f j t}^{s}$ are other determinants of the structure of pay; $d_{t}$ and $d_{j}$ are time and industry dummies; $\eta_{i}$ are individual fixed effects; and $\epsilon_{i f j t}$ is a white noise. That is, the logarithm of compensation, $\ln \left(W_{i f j t}\right)$, contains a fixed component, $A_{i f j t}$, and a variable component, $B_{i f j t}\left(P_{e r f} f j t\right)$, that is a function of firm performance (measured as the logarithm of shareholder's value). Both elements can vary across individuals, firms, and industries. We specify:

$$
A_{i f j t}=a_{0}+a_{1} i m p_{f j t} \quad ; \quad B_{f j t}=b_{0}+b_{1} i m p_{f j t}
$$

where the term $i m p_{f j t}$ is a measure of import penetration (by firm). The reduced-form specification that we estimate is therefore:

$$
\ln \left(W_{i f j t}\right)=a_{0}+a_{1} i m p_{f j t}+b_{0} \operatorname{Perf}_{f j t}+b_{1} i m p_{j t} \operatorname{Perf}_{f j t}+\sum a_{s} X_{i f j t}^{s}+d_{t}+d_{j}+\eta_{i}+\epsilon_{i f j t}
$$

The main coefficients of interest are $a_{1}$, which measures the effect of foreign competition on the fixed component of pay, and $b_{1}$, which captures the differential slope of the performancerelated-pay agreement with respect to different levels of import penetration.

The compensation measure that we use is the log of total pay, and the performance measure is the $\log$ of shareholders' value ${ }^{22}$, so the sensitivity estimates can be interpreted conveniently as elasticities.

Foreign competition, measured as described in the previous section, is demeaned such that $\widehat{b_{1}}$ does not capture any unobserved cross-sectional differences at the sector level that could be correlated with compensation. Controls for firm size (logarithm of assets), year dummies, industry dummies, and a CEO dummy -in the regressions that pool all executives${ }^{23}$, are included in all regressions. Standard errors are clustered at the firm-year level in the regressions where we pool all executives.

Columns 1 to 7 of Table 3 show the OLS estimates of this specification. Increases in import penetration are associated with a lower fixed component of pay $\left(\widehat{b_{0}}<0\right)$ and a variable component of pay that is more sensitive to firm performance $\left(\widehat{b_{1}}>0\right)$. Columns

\footnotetext{
${ }^{22}$ This specification is similar to the ones in Bertrand and Mullainathan (2001) and Murphy (1986) among others. Given that we estimate a fixed-effects specification, it is equivalent to regressing the change in log total pay against the change in shareholders' value, as is frequently done in the corporate finance literature.

${ }^{23}$ Unfortunately, there is only limited biographical information about the executives in the data. Data items such as gender, age, or tenure are only available for a subset of individuals. The fixed-effect regression will capture gender, education, and other time-invariant characteristics, but there is little we can do about the time-varying variables like tenure.
} 
1 to 5 pool all executives while columns 6 and 7 restrict the analysis to company CEOs. Columns 4, 5, and 7 control for time variation in the slope of compensation by interacting time dummies (3 time periods are defined: 1992-1994, 1995-1997, and 1998-2000) with the performance measure, and also allowing for differential slopes across industries (interacting industry dummies with performance).

The effect of import penetration is sizeable. For all executives (Column 2), a 1 percentage point increase in import penetration (one half of a standard deviation) generates an average drop in fixed pay of 6.6 percent and an increase of 1 percent in the sensitivity of pay to performance. Compared with an average sensitivity of $24 \%$ the additional percenctage point implies an increase of $4 \%$ in performance-related pay. For CEOs only (Column 5), the changes are similar and correspond to a 6 percent fall in pay and a 1 percentage point increase in the sensitivity of pay to performance. The magnitudes are very similar (not statistically different) when we look at "stayers" (by including firm-specific individual fixed effects, in Column 3), which indicates that the effect we are capturing operates mostly within firms and is not the result of individuals changing between firms with different compensation structures. The results are also similar, although somewhat smaller in magnitude, when we saturate the model allowing for time trends and permanent cross-industry differences in the slope (Column 4).

Because potential endogeneity is always a concern in these regressions, either because different pay structures lead to management strategies that may preempt foreign competition or because both may be co-determined by some omitted variable, we go on to provide instrumental variable results in Table 4 . The instruments are the weighted real exchange rate of the dollar (current and lagged) and the lagged tariff.

The effect of a 1 percentage point increase (half a standard deviation) in import penetration coming from changes in the exchange rate and tariffs is to reduce the average intercept by 15 percent (19 percent for CEOs in Column 2) and to increase the slope of contracts by 3 percentage points (3.4 percentage points for CEOs, or 15 percent of the baseline sensitivity). The IV effects are larger than the OLS results, which is what we would expect, given that all the sources of bias mentioned would tend to attenuate the coefficient. In the saturated model (Columns 3 and 4) the point estimates are somewhat smaller, but not significantly different in statistical terms.

This is an important result: when firms face additional foreign competition, their pay structure shifts towards more performance-related pay and less fixed pay. That is, compe- 
tition leads to an increase in incentives, and firms shift the components of pay in a way that should induce executives to increase firm performance. This is true if we control for individual fixed effects as well as if we saturate the model with interactions of year and industry dummies with performance. The use of instrumental variables deals with the endogeneity concerns and allows us to confirm that the causality of this effect goes from foreign competition to pay, not the other way around. ${ }^{24}$

Beyond identifying the causal effect in the IV regressions, and to have a sense of the contribution of import penetration to the overall changes in executive compensation and to the increase in performance pay sensitivities, we evaluated the total contribution of import penetration to changing performance-pay sensitivities. In the simple OLS regressions, adding import penetration as a further regressor explains $35 \%$ of the overall increase in performance-pay sensitivities over this period.

\subsection{Promotion and Wage ladders}

Just as tying pay to performance can provide incentives for executives to exert effort and act in the interest of owners, so can the expectation of a promotion and its associated wage increase after good performance. Conversely, the expectation of a potential demotion or firing after poor performance can play the same role. In this section, we analyze how the wage ladder - that is, the wage differentials between executives within a firm that reflect the expected premium associated with a promotion- evolves with foreign competition. ${ }^{25}$

We evaluate changes in pay differentials between the executives of the firm in order to measure whether, as foreign competition increases, executives can expect higher wage increases from moving up the firm's compensation hierarchy. To measure the changes in the promotion ladder, we rank each executive within the firm according to salary and bonus in a given year. ${ }^{26}$ We construct five dummy variables, $h_{k}$ with $k \in\{1,2, . ., 5\}$, where $h_{1}$ takes

\footnotetext{
${ }^{24}$ We also tested the robustness of the results to the inclusion of a number of mechanisms, none of which altered our results. Allowing for relative performance evaluation, and looking at firms with different leverage, made little difference. We also looked for differential effects in firms with different levels of anti-takeover protection, or with large institutional investors, and found no systematic differences.

${ }^{25}$ We investigated whether higher foreign competition led to changes in the probability of a promotion/demotion by studying internal rank mobility. Our regressions related the effect of foreign competition on the probability of an executive changing rank within the firm. We found no significant effects, suggesting that the probability did not change; and therefore, the change in incentives comes from changes in the level of compensation associated with each level in the hierarchy, not from changes in promotion probabilities.

${ }^{26}$ Our data do not allow us to accurately identify whether differences in pay across executives are also linked to differences in job title. That is why our measure of "hierarchy" reflects exclusively pay hierarchy .
} 
value 1 if the executive is the highest paid executive in the firm on a given year and zero otherwise, $h_{2}$ takes value 1 if the executive is the second highest paid executive in the firm on that year, and so on up to $h_{5}$. We then run regressions with the following specification.

$$
\ln \left(W_{i f j t}\right)=a_{0}+\sum_{k=2}^{5} \beta_{k} h_{k}+\sum_{k=2}^{5} \theta_{k} h_{k} i m p_{f j t}+\sum b_{s} X_{i f j t}^{s}+d_{t}+d_{j}+\eta_{i}+\epsilon_{i f j t}
$$

where $i m p_{f j t}$ is import penetration, $X_{i f j t}^{s}$ are control variables (firm size), and the rest of variables are as described in Section 4.1. The coefficients $\beta_{k}$ represent the average wage differential between different levels of executives. Given that the pay measure is in logs, these differentials should be interpreted as ratios of the total pay of one executive to another. Therefore they do not capture the fact that pay increased for all executives during the period. The coefficients of interest are $\theta_{k}$, a measure of the change in these differentials with competition. If the difference in pay between executives increases with $i m p_{f j t}$, we would expect to find that $\beta_{k}$ increases in $k$ (in absolute value); this indicates that the wage differentials are more marked with high foreign competition, conditional on controls and unobserved heterogeneity. Notice that the inclusion of individual fixed effects in these regressions implies that the estimated differences between pay levels, $\beta_{k}$, are not attributable to the different abilities of executives in the hierarchy. That is, if the highest paid worker $(k=1)$ receives a higher wage than the others (reflected by $\left.\beta_{k}<0\right)$, it is not because he or she is the most talented individual, because unobserved ability, that we can think of as "talent", is accounted for in the fixed effect. We present and discuss the results with and without fixed effects. Section 4.3 exploits information in the individual fixed effects about the "talent" of the executives that firms hire, and how this changes with competition.

Table 5 shows the results of this specification. As dependent variables, we use both the $\log$ of total compensation, which reflects overall differences in realized pay, and the log of salary-plus-bonus. The latter may be a better measure of the promotion structure because it is less a reflection of the effort of the executive during year. The omitted category is always the highest paid executive. Before studying the effects of import penetration on the wage differentials within the firm, we analyze the wage ladder itself (coefficients of variables second, third...). By construction, the coefficients are all negative and increasing in absolute value as one goes down the wage ladder. A comparison of Columns 1 and 3 (2 and 4 for total pay) also shows that the wage ladder is less steep when one controls for individual unobserved heterogeneity. This indicates that one of the reasons for existing 
wage differentials among executives is that different levels in the hierarchy are occupied by workers with different ability levels. However, ability (talent) is only part of the explanation, since Columns 3 and 4 still show significant and sizable differences between the different levels. Therefore, "advancing in the pay hierarchy" is associated with a wage increase and thus provides incentives (so long as promotion is tied to performance).

In regard to import penetration, the results on $\theta_{2}$ to $\theta_{5}$ show how imports affect on the differential between the executive layers, net of all characteristics that are controlled for in $X_{i f j t}$ and individual unobserved heterogeneity. These results should not be driven by the fact that individuals with different ability occupy different positions, but rather by how much the firm pays for each position. The coefficients are negative and generally increasing in absolute value with respect to the import penetration measure. As import penetration increases, the wage schedule becomes steeper, with the highest paid executive earning proportionally more than the second highest paid executive, and so on, for all 5 categories.

Again, the effect is sizeable: for the highest paid executive, a single standard deviation increase in foreign competition generates a 2.25 percent increase in salary-plus-bonus and a 1.8 increase in total pay (which includes fixed and variable pay). It also leads to an additional wage differential -after controlling for ability in Columns 3 and 4- between the highest and the fifth highest paid executive of 1.6 percent in salary-plus-bonus, and 1 percent in total compensation (although the difference is not highly significant).

Comparing Columns 1 and 3 also shows that the increase in the top executive pay with imports is slightly higher if we do not include individual fixed effects (in Column 1). This suggests that some of the increase in CEO pay is a result of firms in more competitive industries hiring more skilled/talented CEOs. Frydman (2005) and Murphy et al. (2004) argue that the increase in CEO pay reflects an increase in the demand for general skills. Our results suggest that this increase in the demand for talent may arise from increased foreign competition.

To assess the causal effect of foreign competition, we use instrumental variables as before. Columns 5 and 6 mirror the specifications in columns 3 and 4 (with imports instrumented) and yield a similar pattern, although the magnitude of the effects is larger throughout. Salary-plus-bonus of the highest paid executive increases by 22 percent and the difference in comparison to the fifth executive is 6 percent larger after a single standard deviation (2 percentage points) increase in import penetration (16 percent and 9 percent respectively 
for total compensation in Column 8). In these specifications, total pay for the lower ranked executives actually falls.

In sum, these results indicate that the ratio of the total pay of an executive to the total pay of the next lower paid executive grows with foreign competition. This leads to higher rewards for an internal promotion, and is one way to provide incentives that complements the increase in performance-pay sensitivities documented in the last section. The results also complement those in the previous section in terms of the overall effect on total pay of changing compensation structures: total pay increases at the top of the ladder and falls for lower ranked executives (Columns 7 and 8). This is related to the results in Revenga (1992), Abowd and Lemieux (1992), and Abowd and Allain (1996), who analyze workers and find a negative effect on total pay of increasing foreign competition. We find that compensation actually may increase for the very top executives; that this increase is partly a result of firms hiring more highly skilled executives; and that total compensation falls more, the lower in the hierarchy the executive is. ${ }^{27}$

\subsection{Talent}

The previous section suggested that changes in wage differentials were partly attributable to firms hiring workers with different talent (measured as the unobserved fixed component of wages). Marin and Verdier (2003a and 2003b) argue that increased globalization and international trade lead firms to demand more talent (to a "war for talent") as the market becomes more competitive, and to the extent that talent is in limited supply. In this section we evaluate empirically whether firms tend to attract more or less talented CEOs and executives as import penetration increases. Of course, we cannot see how demand changes, but only what the realization of talent is in the firm.

The previous section also showed that total pay for the CEO and the very top executives within the sample goes up. As mentioned, Murphy and Zabojnik (2004) and Frydman (2005) suggest that the increase in the level of CEO pay may be a result of increased demand for managerial talent. This section complements their results to the extent that we provide

\footnotetext{
${ }^{27}$ To assess the channels through which competition operates, we also checked whether the effect of imports on pay sensitivities and on hierarchies was different across firms with different governance levels (as measured by the presence of a large institutional investor, and by the Gompers-Ishii-Metrick index). The results indicated that, if anything, the effect is larger for low governance firms, suggesting there is a catch-up effect at work. However the differences were not statistically significant in most cases. Results are available upon request.
} 
evidence here for changes in the observed distribution of talent at the top of the firm and that we are able to systematically test whether competition is one reason for this increase in the demand for managerial ability.

Finding good measures of executive talent is not straightforward; however, a fairly good proxy for ability can be derived from the fixed-effects regressions. The individual fixed effect in a panel regression captures any fixed unobserved component that is not explicitly controlled for and that determines wages. The logarithm of total compensation is determined by a set of observables (like performance, firm size, industry, etc.) and an unobserved fixed component that the individual carries with him from one firm to another. In the labor literature, this term is interpreted as unobserved ability. We call this ability, or talent, interchangeably.

We first model compensation as:

$$
\ln \left(W_{i f j t}\right)=\alpha+\beta_{1} i m p_{f j t}+\sum_{k=1}^{5} \beta_{2}^{k} h_{k}+\beta_{3} \ln \text { assets }_{f j t}+d_{t}+d_{j}+\eta_{i}+\epsilon_{i f j t}
$$

where variables are defined as above. In particular, $h_{k}$ are dummies indicating the level $(k)$ in the hierarchy occupied by the worker. From this we estimate an individual fixed effect $\widehat{\eta}_{i}$. The fixed effects are estimated on the full Execucomp sample, not just on the restricted sample for which we have trade information.

Notice that this estimate does not include the fact that wages may be higher because of higher import penetration, nor that workers receive different wages at different levels in the hierarchy $\left(h_{k}\right)$ because of incentive effects. Nor does it include firm size effects, or any aggregate trend in wages, or cross-industry differences in wages. The estimate $\widehat{\eta}_{i}$ is net of all those effects. However, it will include things such as innate talent, ability, and education (not explicitly controlled for and arguably constant over time for executives). ${ }^{28}$ Studying $\widehat{\eta}_{i}$ shows what type of workers firms hire over time. For instance, the $\widehat{\eta}_{i}$ associated with the the highest paid worker of a given firm (the talent of that executive) will change over time, when he is replaced. So, we can define $\widehat{\eta}_{i f t}^{1}$ as the fixed effect estimated for the highest paid worker of firm $f$ at time $t$. Similarly, one can define $\widehat{\eta}_{i f t}^{k}$ as the talent of each of the $k$ executives in the firm's hierarchy. Thus, for each $k$ we can estimate:

$$
\widehat{\eta}_{i f t}^{k}=\lambda+\gamma i m p_{f j t}+\phi_{f}+u_{i f j t}
$$

\footnotetext{
${ }^{28}$ This regression does not include performance, given that if an individual with higher ability leads the firm to perform better, we do not want to net this out of our ability estimate.
} 
where $\phi_{f}$ are firm fixed effects. Here, the identification comes from firms who replace their $k^{\text {th }}$ executive: that is, from the change in talent from one executive to his successor.

Table 6 presents the results of the talent regressions. Column 1 restricts the analysis to the company $\mathrm{CEO}(k=C E O)$ and shows that as firms face more competition, they replace their CEOs with more talented individuals. This is only identified through movers -firms that change their CEO. The effect is larger for the instrumented regression, shown in the second panel.

Columns 2 to 6 show the results for each level of the hierarchy, $k=1$ to 5 . We find that the highest paid executive hired has higher talent as imports increase ${ }^{29}$. As we go further down the hierarchy, we find as shown in the non-instrumented regressions (panel 1), that the change in talent of lower-ranked executives is smaller if anything, although there are no significant coefficients. In panel 2, when import penetration is instrumented, we show that the talent of the highest ranked executive is higher; the talent of the second ranked executive does not change significantly; and the talent of the third and fourth ranked executives falls. All of these results are identified out of within-firm and hierarchical-level changes in executive talent when a number of observables are netted out of the wage regressions.

In sum, we conclude that the distribution of talent within the firm changes, with firms hiring more talented workers at the top as they face more competition. This is particularly clear in the IV regressions, which arguably are identifying a causal effect. Therefore, firms not only try to elicit more effort from workers through incentives (as shown in Sections 4.1 and 4.2) but also seem to attract more talented workers. These results are consistent with the predictions of the model in Marin and Verdier (2003) and suggest that there may be a war for talent playing out when markets are more globalized. ${ }^{30}$ Furthermore, from an organizational perspective, the results suggest that talent matters "at the top". When faced with competitive pressure, firms seem to want to ensure that the CEO and the top executives are high performers, probably because their marginal contribution to the success of the firm is much larger.

\footnotetext{
${ }^{29}$ The coefficient is different from that of CEOs because it is not always the case that the CEO is the highest paid executive.

${ }^{30}$ It also provides support for and complements the arguments in Murphy and Zabojnik (2004) and Frydman (2005).
} 


\subsection{Job Mobility: Turnover}

Next we explore whether the probability of an executive exiting the firm is affected by foreign competition. We know from Huson et al. (2001), that since the 1970s, the hiring of outside CEOs and forced CEO succession have increased. An increase in the probability of either voluntary departures (through external promotion) or involuntary ones (through forced retirement or firing) in principle should increase the incentives of the executive to exert effort and thus increase the performance of the firm. Since we have a panel of executives, we can use survival analysis methods to analyze the effect of foreign competition on the probability of turnover. Using this type of estimation method is important, because the probability that an individual exits the firm in a given period is not independent of how long he has been in the firm. Therefore, we want to model the underlying time-dependence (captured by the baseline hazard) and assess how foreign competition alters the probability of exit.

Executives may exit the firm because they are fired, hired by a rival firm, or they retire. The motivations behind each of these are clearly different. Unfortunately, Execucomp data are not well suited to a detailed analysis of this question because, even though they contain a variable that reports why an executive leaves the firm, this information is not very reliable. First, the set of reasons listed is not exhaustive (in particular, no executive reports a firing); second, for most executives no reason is reported; finally, the incentives to misreport the true motives are strong, given that Execucomp is effectively a non-anonymous dataset. Therefore, we are left with an indicator for exit from the firm, that groups all of these reasons together and estimate whether job turnover in general changes with foreign competition.

A second, more important limitation concerns the available information on entry. Execucomp only reports the date when the executive effectively entered the firm for a subset of observations. This poses two problems. First, for a large number of observations, we do not know when the individual entered the firm; therefore, we do not know exactly when these observations started being at risk of exiting. We simply observe when the individual became one of the top 5 executives while the firm was in the sample. This left-censoring leads us to drop those observations. Second, even for those who report an entry date, we only observe individuals who survived until the moment they were included in the sample. All those executives who entered and exited the firm before the firm entered the sample are not observed (along with those who never made it to the top 5). Therefore, longer durations 
are more likely to appear in the sample, and this may be a source of selection bias. We deal with this type of left-truncation in the estimation.

With the limitations of the data in mind, we first plot Kaplan-Meier survival functions to see the effect of high foreign competition on turnover patterns. Because we need entry dates to do this, we restrict the sample to individuals who report their date of entry to the firm. We classify individuals according to whether they are in industries with above or below average levels of foreign competition. ${ }^{31}$ This is shown in Figure 2. The vertical axis represents the probability of staying in the same firm after a given number of years (represented in the horizontal axis). Figure 2 indicates that individuals in industries with high foreign competition (above average import penetration) are more likely to exit the firm (less likely to survive, their Kaplan-Meier survival function drops faster). Therefore, turnover (exit from the firm) seems to be higher in high-foreign-competition industries. However, when the sample is divided according to the predicted import penetration using instrumental variables (Figure 3), the results are quite different, and show a much more similar survival pattern for both high and low predicted import penetration groups.

This graphical analysis does not allow us to control adequately for the structure of the data (the left-truncation and the potential survivor bias), nor for other covariates that may be correlated with imports and determine the exit probability. Table 7 shows the results of the hazard estimation taking into account the right-censoring, left-truncation and discrete nature of the data, and controlling for CEO status, firm performance and firm size (as the logarithm of assets). We estimate a logistic hazard model with a baseline hazard defined as the logarithm of duration time $(\ln (t))^{32}$ and restricting the analysis to the observations for which we observe entry.

The analysis reveals that the probability of exit from the firm increases with import penetration, but this is largely a result of exit probabilities and imports trending in the same direction over time. Once we control for year dummies (Column 2), the significance of the coefficient in Column 1 disappears, although it is still positive. When using the predicted value of imports (using our instruments) as a regressor (Columns 3 and 4) instead of the actual value, we find no significant effect of imports on the probability of exit. If anything,

\footnotetext{
${ }^{31}$ We define them relative to the industry average. Graphs using the deviation with respect to the overall (economy wide) import penetration average were qualitatively similar. However, to avoid identifying the results out of the cross-sectional variation in imports, we favored the industry-specific average.

${ }^{32}$ We model the baseline hazard as $\ln (\mathrm{t})$. The results were basically identical when using a non-parametric baseline, but we lost many observations because of the inclusion of dummies.
} 
this is negative (not significant) in Column 4 with controls for year dummies. We do find in all of the specifications that higher performance reduces the probability of exiting the firm and that executives in large corporations are more mobile. Further, CEOs also have a lower probability of exit. However, since our measure does not distinguish between voluntary and involuntary exits, it is hard to draw conclusions beyond these general descriptive results.

Overall, the results do not suggest a strong relationship between turnover and competition: turnover is positively related to increases in import penetration, but this seems to be the result of a secular trend rather than a response to the exogenous changes induced by exchange rates and tariffs. One possible explanation for this effect is that firms decide to change their CEOs when they expect increases in competition, but are reluctant to do so once competition has already increased and the firm is under stress. However, with these data and results, there is little more we can say other than to point to weak a correlation between turnover and foreign competition.

\section{Conclusion}

In this paper we identify the effects of foreign competition on different aspects of executive pay and the provision of incentives within the firm. Eliciting the empirical interaction between competition and the provision of incentives is particularly important, as the existing theoretical predictions are largely ambiguous.

Our results show that increases in foreign competition are associated with lower levels of fixed pay and a higher sensitivity of pay to performance. Furthermore, and in contrast to the literature relative to foreign competition and general wages, we do not find a consistent decrease in total pay across all executives associated with more competition. Instead, we observe that the wage ladder of the firm becomes steeper with more competition; that is, the highest paid executives in the firm tend to earn proportionally more when competition is high, while the lower layers of executives earn less as competition increases. All of these results indicate that the incentives that the firm provides to executives to improve the performance of the firm increase with foreign competition. We also show that higher foreign competition leads to a higher demand for talent, especially at the very top layers of the firm hierarchy and in particular for the CEO. Finally, we find some evidence that the probability of exiting the firm (either through an external promotion, because the executive gets fired or for any other reason) increases with foreign competition. This is likely to induce executives to work harder, particularly in connection with the increased span of 
wage schedules. However, this last effect seems to be related only to changes in expected competition; no causal effect of competition on turnover beyond the initial correlation can be convincingly established.

The fact that we find a causal effect of foreign competition -measured in a very precise way and instrumented- on incentive provision across a number of different incentive mechanisms lends credibility to the idea that firms faced with more competition increase incentive provision. Our results also provide a causal explanation for the observed changes in the levels of compensation, and show that part of the relative increase in compensation of CEOs with respect to other executives is attributable to an increased demand for managerial talent. There are certainly other reasons why compensation structures may have changed over time. We established that one important contributor is the extent of import penetration and the implied increase in product-market competition. Developing our understanding of these mechanisms further is left to future research.

\section{References}

[1] Abowd, John M.; Thomas Lemieux (1993) 'The effects of product market competition on collective bargaining agreements: the case of foreign Competition in Canada' Quarterly Journal of Economics, vol 108, 4, Pages: 983-1014

[2] Abowd John M, Laurence Allain (1996) 'Compensation Structure and Product Market Competition 'Annales d'Economie et de Statistique, 41/42 (January/June) pages 207218.

[3] Aggarwal, Rajesh K.; Andrew A. Samwick; (1999) Executive Compensation, Strategic Competition, and Relative Performance Evaluation: Theory and Evidence; Journal of Finance, December, v. 54, iss. 6, 1999-2043

[4] Antras, Pol; Garicano, Luis; Rossi-Hansberg, Esteban (2006) 'Offshoring in a Knowledge Economy' Quarterly Journal of Economics, February

[5] Baldwin, Richard (1988). 'Hyteresis in Import Prices: The Beachhead Effect,' American Economic Review, Vol. 78 (4) pp. 773-85.

[6] Baldwin, Richard and Paul Krugman (1989) 'Persistent Trade Effects of Large Exchange Rate Shocks,' The Quarterly Journal of Economics Vol. 104. No. 4 (Nov) pp. $635-654$

[7] Bertrand, Marianne (2004) 'From the Invisible Handshake to the Invisible Hand? How Import Competition Changes the Employment Relationship' Journal of Labor Economics, volume 22 , page 723

[8] Bertrand, Marianne; Mullainathan, Sendhil (2001) 'Are CEOs Rewarded for Luck? The Ones Without Principals Are', The Quarterly Journal of Economics, 116(3), August 901-32 
[9] Cuñat, Vicente; Guadalupe, Maria (2004) 'Executive Compensation and Competition in the Banking and Financial Sectors', CEPR Discussion Papers 4425.

[10] Cuñat, Vicente; Guadalupe, Maria (2005), 'How Does Product Market Competition Shape Incentive Contracts?', Journal of the European Economic Association Vol 3, 5.

[11] Dixit, Avinash (1989). 'Hysteresis, Import Penetration, and Exchange Rate PassThrough,' Quarterly Journal of Economics, Vol.104, No.2 (May). pp. 205-28.

[12] Feenstra, Robert C., Romalis, John; Schott, Peter K. (2002) 'US Imports, Exports and Tariff Data, 1989-2001' NBER Working Papers No. w9387

[13] Frydman, Carola (2005) 'Rising Through the Ranks. The Evolution of the Market for Corporate Executives, 1936-2003', Harvard mimeo

[14] Gabaix, Xavier; Augustin Landier (2006) 'Why Has CEO Pay Increased So Much?' MIT Department of Economics Working Paper No. 06-13. May 8.

[15] Galdon-Sanchez, Jose E. ; Schmitz, James A. (2002) 'Competitive Pressure and Labor Productivity: World Iron-Ore Markets in the 1980s,' American Economic Review, Vol. 92 (4) pp. 1222-1235.

[16] Gibbons, Robert (2005) 'Incentives Between Firms (and Within)' Management Science, Volume 51, Number.1 pp.2-17.

[17] Gibbons, Robert; Waldman, Michael (1999) 'Careers in Organizations: Theory and Evidence' in Handbook of Labor Economics, Vol. 3, O. Ashenfelter and D. Card, eds.(Amsterdam, The Netherlands: North-Holland,), pp. 2373-2437.

[18] Guadalupe, Maria (2004) 'Product Market Competition, Returns to Skill and Wage Inequality' CEPR Discussion Paper, June, 4434.

[19] Hart, Oliver (1982) 'The Market Mechanism as an Incentive Scheme', Bell Journal of Economics 74 , 366-682

[20] Hermalin, Benjamin E. (1992) 'The Effects of Competition on Executive Behavior' RAND Journal of Economics, The RAND Corporation, vol. 23(3), pp. 350-365.

[21] Huson, Mark R., Robert Parrino and Laura T. Starks (2001) 'Internal Monitoring Mechanisms and CEO Turnover: A Long-Term Perspective' Journal of Finance Vol.56 pp.2265-2297.

[22] Katz, Lawrence F.; Autor, David H (1999) 'Changes in the Wage Structure and Earnings Inequality' Handbook of Labor Economics, vol. 3A, O. Ashenfelter and D. Card, eds., North-Holland, 1999, 1463-1555.

[23] Kramarz, Francis (2006) 'Unions, Imports, and Wages: Evidence from data matching imports, firms, and workers', mimeo

[24] Lemieux, Thomas; Manleod, Bentley W.; Parent, Daniel (2005) 'Bonus Pay and Wage Inequality', mimeo 
[25] Marin, Dalia; Verdier,Thierry (2003a) 'Globalization and the New Enterprise' Journal of the European Economic Association, MIT Press, vol. 1(2), pages 337-344.

[26] Marin, Dalia; Verdier, Thierry (2003b).'Globalization and the Empowerment of Talent' CEPR Discussion Papers 4129, C.E.P.R. Discussion Papers.

[27] Murphy, Kevin J. (1986) 'Incentives, Learning, and Compensation: A Theoretical and Empirical Investigation of Managerial Labor Markets', Rand Journal of Economics, 17(1), Spring, 59-76.

[28] Murphy, Kevin J. (1999) 'Executive Compensation' Handbook of Labor Economics. Volume 3b pp. 2485-2563.

[29] Murphy, Kevin J.; Zábojník, Ján (2004a) 'CEO Pay and Appointments: A MarketBased Explanation for Recent Trends', American Economic Review, American Economic Association, vol. 94(2), pp. 192-196.

[30] Murphy, Kevin J.; Zábojník, Ján (2004b) 'Managerial Capital and the Market for CEOs', Working Paper (October).

[31] Nickell, Stephen J. (1996), 'Competition and Corporate Performance,' Journal of Political Economy, Vol. 104, Issue 4 pp. 724-46.

[32] Raith, Michael (2003). 'Competition, Risk and Managerial Incentives,' American Economic Review, Vol. 93, pp. 1425-1436.

[33] Rajan, Raghuram; Wulf, Julie (2006) 'The Flattening Firm: Evidence from Panel Data on the Changing Nature of Corporate Hierarchies' Review of Economics and Statistics, forthcoming.

[34] Revenga, Ana L. (1992) 'Exporting Jobs? The Impact of Import Competition on Employment and Wages in U.S. Manufacturing' Quarterly Journal of Economics, volume 107, 1 pp. 255-284.

[35] Scharfstein, David; (1988) 'Product-Market Competition and Managerial Slack' The RAND Journal of Economics, Vol.19 No.1 Spring, 147-155

[36] Schmidt, Klaus M. (1997). 'Managerial Incentives and Product Market Competition,' Review of Economic Studies, Vol. 64, Issue 2 (April) pp. 191-213.

[37] Slaughter, Matthew (1998) 'International Trade and Labour-Market Outcomes: Results, Questions, and Policy Options' The Economic Journal, 108 (450), pp. 1452-1462.

[38] Tybout, James R. (2003) 'Plant-and Firm-level Evidence on the 'New' Trade Theories' in E. Kwan Choi and James Harrigan, ed., Handbook of International Trade, Oxford: Basil-Blackwell.

[39] Vives, Xavier (2004). 'Innovation and Competitive Pressure', CEPR Discussion Paper, April, No. 4369. 


\section{Data Appendix}

\section{Execucomp dataset:}

A panel that records information on at least the top 5 executives of the firms included in the S\&P1500 index from 1992 onwards. We concentrate on the firms in industries for which we have import penetration (the manufacturing sector in 1992-1999). We also restrict the sample to the top five executives of each firm (ranked by salary-plus-bonus) and drop the observations where there is no information on total pay received by the executive. This leaves 17,178 executive-year observations.

\section{Trade Data:}

Import Penetration: Import penetration is defined at the industry level at 4 digit SIC as the ratio of imports over imports plus domestic production in that year. We take the average of contemporary and one year forward lag import penetration by industry. This is demeaned at the industry level. For each firm, we construct weights that correspond to the fraction of sales associated to each industry (business segment in Compustat) in which it operated in 1991. The final import penetration measure is the weighted average of all manufacturing industries in which the firm operates in 1991 . Since the industries the firm operates in may change endogenously over time, the weights used correspond to the firm's operations in 1991. (Source: NBER database "US Imports, Exports and Tariff Data, 1989-2001 (NBER 9387)" and Compustat Segments data)

Tariffs: The average tariff measure is defined as the weighted average of the tariffs imposed by the US on imports to each country, where the weights are the fraction of imports coming from each country in 1993. (Source: UNCTAD TRAINS dataset)

Exchange rates: The exchange rate index is defined as in Bertrand (2004) at the industry level (3 digit SIC code) as the weighted average of the log real exchange rates of importing countries (expressed in foreign currency per dollar), where the weights are the share of each foreign country's import on total imports in a base period (1990-1991). Real exchange rates are nominal exchange rates multiplied by US Consumer Price Index and divided by the trading partner CPI. Nominal exchange rates and foreign CPIs are obtained from the International Financial Statistics of the IMF.

Tariffs and exchange rates are also weighted to obtain the firm specific measure.

All the trade information is obtained from the NBER database "US Imports, Exports and Tariff Data, 1989-2001 (NBER 9387)". The tariff information is from UNCTAD TRAINS dataset and the information on domestic production is from Census Bureau's Annual Survey of Manufactures (Statistics for Industry Groups and Industries) provided by the Bureau of Economic Analysis.

\section{Duration Analysis:}

To construct employment durations and transitions, we exploit the panel. Each executive has a unique identifier (variable EXECID) that allows us to follow him over time, provided job changes occur within the Execucomp sample. We identify as firm transitions:

-observations where the firm reports that the executive left the sample in that particular year (variable leftco).

-transitions in which we observe the individual in a firm one year and in another firm the year after (coded as exit from the firm);

-transitions in which we observe the individual in a firm one year and not the following year, although the firm remains in the sample (the individual may have moved to a firm outside the sample).

All other spells are considered as censored. In particular, if the firm exits the sample 
we consider all executive observations in that firm as censored on the year the firm exits the sample.

We also need to restrict the sample to those individuals for whom an entry date into the firm is reported because of the left-truncation problem.

\section{Tables and Figures}

Table 1: Summary Statistics

\begin{tabular}{lcccccc} 
Variable & Mean & S.D. & 0.25 & $\mathrm{Mdn}$ & 0.75 & $\mathrm{~N}$ \\
\hline \hline & & & & & & \\
Ln total pay & 6.96 & 0.95 & 6.28 & 7.00 & 11.92 & 23796 \\
Ln salary + bonus & 6.35 & 0.74 & 5.83 & 6.40 & 6.86 & 23793 \\
Ln Performance & 7.45 & 1.76 & 6.09 & 7.37 & 8.64 & 23796 \\
Import pen.(demeaned) & 0.00 & 0.02 & -0.09 & -0.03 & 0.03 & 23796 \\
Import pen *Ln performance & -0.01 & 0.13 & -0.09 & -0.03 & 0.03 & 23796 \\
Ln assets & 7.27 & 1.88 & 5.85 & 7.23 & 8.62 & 23796 \\
CEO & 0.27 & 0.45 & 0 & 0 & 0 & 23796 \\
Exchange rate & 1.96 & 0.73 & 1.46 & 1.98 & 2.56 & 23796 \\
Tariffs (lag) & 3.14 & 4.83 & 0.89 & 2.66 & 4.27 & 13293 \\
\hline \hline
\end{tabular}

Notes: Total pay is total yearly compensation that includes salary, bonus, total value of stock options granted (valued using the standard Black-Scholes formula), total value of restricted stock granted, long-term incentive payouts and other annual compensation; Performance is the natural logarithm shareholders value at fiscal year end (in \$1000) ; Import Penetration is Imports divided by Imports plus domestic production at 4 digit SIC, the variable at t is the average of its value $t$ and $t+1$ and is demeaned with respect to the industry average; Log assets measures firm size; CEO is an indicator for who is the company CEO; Exchange rate is the weighted average of the log real exchange rates of importing countries (expressed in foreign currency per dollar), where the weights are the share of each foreign country's import on total imports in a base period (1990-1991); Tariff is the weighted average of tariffs paid by importers where the weights are the importance of each country's imports in the base year. Weights are firm specific and measured by the fraction of sales in each of the firm's segments in 1991. See data appendix for further details and sources. 
Table 2: First stage

\begin{tabular}{|c|c|c|c|c|}
\hline & $\begin{array}{c}\text { Import Pen. } \\
1\end{array}$ & $\begin{array}{l}\text { Import Pen. } \\
2\end{array}$ & $\begin{array}{c}\text { Import Pen.*Perf } \\
3\end{array}$ & $\begin{array}{c}\text { Export Open. } \\
4\end{array}$ \\
\hline \multirow[t]{2}{*}{ Exchange Rate } & -0.004 & -0.005 & $0.114^{* * *}$ & 0.002 \\
\hline & {$[0.003]$} & {$[0.006]$} & {$[0.033]$} & {$[0.018]$} \\
\hline \multirow[t]{2}{*}{ Lagged Exchange Rate } & $-0.029 * * *$ & -0.011 & $-0.274^{* * *}$ & 0.022 \\
\hline & {$[0.008]$} & {$[0.009]$} & {$[0.061]$} & {$[0.048]$} \\
\hline \multirow[t]{2}{*}{ Lagged Tariffs } & $-0.0002^{* * *}$ & $-0.002^{* * *}$ & $-0.006^{* *}$ & $-0.002^{*}$ \\
\hline & {$[0.000]$} & {$[0.001]$} & {$[0.003]$} & {$[0.001]$} \\
\hline \multirow[t]{2}{*}{ Performance } & & $0.007 * * *$ & $0.061^{* * *}$ & \\
\hline & & {$[0.002]$} & {$[0.015]$} & \\
\hline \multirow[t]{2}{*}{ Exchange Rate ${ }^{*}$ Performance } & & 0 & $-0.019 * * *$ & \\
\hline & & {$[0.001]$} & {$[0.005]$} & \\
\hline \multirow[t]{2}{*}{ Lagged Exch. Rate $*$ Performance } & & $-0.003^{* * *}$ & 0.007 & \\
\hline & & {$[0.001]$} & {$[0.008]$} & \\
\hline \multirow[t]{2}{*}{ Lagged Tariffs*Performance } & & $0.000 * * *$ & $0.001^{*}$ & \\
\hline & & {$[0.000]$} & {$[0.000]$} & \\
\hline Year Dummies & yes & yes & yes & yes \\
\hline Industry Dummies & yes & yes & yes & yes \\
\hline Indiv. Fixed Effects & yes & yes & yes & yes \\
\hline Observations & 18251 & 18251 & 18251 & 13313 \\
\hline R-squared & 0.282 & 0.288 & 0.303 & 0.022 \\
\hline $\mathrm{R}$ squared excl. IV & 0.08 & 0.09 & 0.11 & \\
\hline Joint significance of IV (F-stat) & 101.3 & 45.92 & 54.26 & \\
\hline Hansen Overid test $\mathrm{P}$-value & 0.098 & 0.469 & 0.469 & \\
\hline \multicolumn{2}{|c|}{$*$ significant at $10 \% ; * *$ at $5 \% ; * * *$ at $1 \%$} & & & \\
\hline \multicolumn{5}{|c|}{$\begin{array}{l}\text { Notes: This are the first stage regressions for the main endogenous variables instrumented in } \\
\text { sections } 4.1 \text { (Column } 1 \text { ) and } 2 \text { (Columns } 2 \text { and } 3 \text { ). The dependent variable is Import penetration } \\
\text { in columns } 1,2 \text { and } 4 \text {, and Import penetration times performance in column } 3 \text {. All regressions } \\
\text { include the explanatory variables of the second stage in addition to the variables and instruments } \\
\text { reported on the table. Import penetration is imports divided by Imports plus domestic produc- } \\
\text { tion at } 4 \text { digit SIC, the variable associated to period t is the average of the ratio in period t and } \\
\text { period t+1, the variable is demeaned with respect to the industry average; Performance is the } \\
\text { natural logarithm of shareholders value at fiscal year end; Exchange rate is the weighted average } \\
\text { of the log real exchange rates of importing countries (expressed in foreign currency per dollar), } \\
\text { where the weights are the share of each foreign country's import on total imports in a base period } \\
\text { (1990- } 1991 \text { ); the weights correspond to the primary sector of the firm in columns } 1 \text { and } 2 \text { and } \\
\text { to the weighted average of all the segments of the firm according to their relative importance } \\
\text { in } 1991 \text {. Tariff is the weighted average of duties imposed on imports, where the weights are the } \\
\text { fraction of imprts form each trading country in that industry in a base year. See data appendix } \\
\text { for further details and sources. }\end{array}$} \\
\hline
\end{tabular}


Table 3: Pay Structure: Performance-related-pay

\begin{tabular}{|c|c|c|c|c|c|c|}
\hline & $\begin{array}{c}\text { Total comp. } \\
1\end{array}$ & $\begin{array}{c}\text { Total comp. } \\
2\end{array}$ & $\begin{array}{c}\text { Stayers } \\
3\end{array}$ & $\begin{array}{c}\text { Total comp.+trends } \\
4\end{array}$ & $\begin{array}{c}\text { CEOs } \\
5\end{array}$ & $\begin{array}{c}\text { CEOs+trends } \\
6\end{array}$ \\
\hline \multirow[t]{2}{*}{ Performance } & $0.20^{* * *}$ & $0.24^{* * *}$ & $0.24^{* * *}$ & $-1.61^{* * *}$ & $0.32^{* * *}$ & -0.39 \\
\hline & {$[0.01]$} & {$[0.02]$} & {$[0.02]$} & {$[0.18]$} & {$[0.02]$} & {$[2.09]$} \\
\hline \multirow[t]{2}{*}{ Import Pen. } & $-4.78^{* * *}$ & $-6.61^{* * *}$ & $-5.74 * * *$ & $-4.19^{* *}$ & $-6.54^{* * *}$ & -3.79 \\
\hline & {$[1.57]$} & {$[1.78]$} & {$[1.79]$} & {$[1.93]$} & {$[2.28]$} & {$[2.91]$} \\
\hline \multirow[t]{2}{*}{ Import Pen.*Mk.Ret. } & $0.80^{* * *}$ & $0.98^{* * *}$ & $0.86^{* * *}$ & $0.63^{* *}$ & $1.04^{* * *}$ & $0.73^{*}$ \\
\hline & {$[0.23]$} & {$[0.26]$} & {$[0.26]$} & {$[0.29]$} & {$[0.31]$} & {$[0.41]$} \\
\hline \multirow[t]{2}{*}{ Ln Assets } & $0.19^{* * *}$ & 0.03 & 0.04 & 0.03 & $0.06^{*}$ & 0.05 \\
\hline & {$[0.01]$} & {$[0.03]$} & {$[0.03]$} & {$[0.03]$} & {$[0.04]$} & {$[0.04]$} \\
\hline \multirow[t]{2}{*}{$\mathrm{CEO}$} & $0.85^{* * *}$ & $0.24^{* * *}$ & $0.23^{* * *}$ & $0.25^{* * *}$ & & \\
\hline & {$[0.01]$} & {$[0.02]$} & {$[0.02]$} & {$[0.02]$} & & \\
\hline \multirow[t]{2}{*}{ Performance*trend1995-1997 } & & & & $0.04^{* * *}$ & & \\
\hline & & & & {$[0.01]$} & & \\
\hline \multirow[t]{2}{*}{ Performance*trend1998-1999 } & & & & $0.04^{* * *}$ & & \\
\hline & & & & {$[0.01]$} & & \\
\hline Year + Ind. Dummies & yes & yes & yes & yes & yes & yes \\
\hline Indiv Fixed Effects & no & yes & yes & yes & yes & yes \\
\hline Indust.dummies*Perf. & no & no & no & no & no & yes \\
\hline Year dummies*Perf. & no & no & no & no & no & yes \\
\hline Observations & 23222 & 23222 & 23222 & 23222 & 4157 & 4157 \\
\hline R-squared & 0.6 & 0.84 & 0.85 & 0.85 & 0.82 & 0.84 \\
\hline \multicolumn{7}{|c|}{ Robust standard errors in brackets, clustered by firm-year } \\
\hline \multicolumn{7}{|c|}{$\begin{array}{l}\text { Notes: The dependent variable, is the log of total yearly compensation that includes salary, bonus, total value of } \\
\text { stock options granted (valued using the standard Black-Scholes formula), total value of restricted stock granted, } \\
\text { long-term incentive payouts and other annual compensation; Performance is the natural logarithm shareholders } \\
\text { value at fiscal year end ; Import Penetration is Imports divided by Imports plus domestic production at } 4 \text { digit } \\
\text { SIC, the variable is the average of the contemporaneous ratio and a forward lag and iis demeaned with respect } \\
\text { to the industry average; Log assets measures firm size; CEO is an indicator for who is the company CEO. See } \\
\text { data appendix for further details and sources. }\end{array}$} \\
\hline
\end{tabular}


Table 4: Pay Structure: IV Results

\begin{tabular}{|c|c|c|c|c|}
\hline & All & CEOs & All & CEOs \\
\hline & 1 & 2 & 3 & 4 \\
\hline \multirow[t]{2}{*}{ Performance } & $0.16^{* * *}$ & $0.22^{* * *}$ & $0.15^{* * *}$ & $0.20^{* * *}$ \\
\hline & {$[0.03]$} & {$[0.04]$} & {$[0.03]$} & {$[0.05]$} \\
\hline \multirow[t]{2}{*}{ Import Pen. } & $-14.59 * * *$ & $-19.41 * * *$ & $-16.28 * * *$ & $-22.89^{* * *}$ \\
\hline & {$[4.77]$} & {$[6.74]$} & {$[4.39]$} & {$[7.48]$} \\
\hline \multirow[t]{2}{*}{ Import Pen.*Mk.Ret. } & $3.04^{* * *}$ & $3.41^{* * *}$ & $3.00^{* * *}$ & $3.97^{* * *}$ \\
\hline & {$[0.64]$} & {$[0.89]$} & {$[0.60]$} & {$[1.04]$} \\
\hline \multirow[t]{2}{*}{ Ln Assets } & $0.12^{* * *}$ & $0.09^{*}$ & $0.11^{* * *}$ & $0.10^{* *}$ \\
\hline & {$[0.03]$} & {$[0.05]$} & {$[0.03]$} & {$[0.05]$} \\
\hline \multirow[t]{2}{*}{$\mathrm{CEO}$} & $0.28^{* * *}$ & & $0.28^{* * *}$ & \\
\hline & {$[0.02]$} & & {$[0.02]$} & \\
\hline Year + Ind. Dummies & yes & yes & yes & yes \\
\hline Indiv Fixed Effects & yes & yes & yes & yes \\
\hline Indust.dummies*Perf. & no & no & yes & yes \\
\hline Year dummies*Perf. & no & no & yes & yes \\
\hline Observations & 18251 & 3531 & 18251 & 3531 \\
\hline $\mathrm{R}$ squared & 0.14 & 0.17 & 0.19 & 0.22 \\
\hline Robust standard errors & n brackets & & & \\
\hline$*$ significant at $10 \%$;* & $5 \% ; * * *$ & $1 \%$ & & \\
\hline
\end{tabular}

Notes: These are two stage least squares regressions of table 3 where Import Penetration and its interaction with Performance are instrumented with exchange rates and tariffs (see table 2 for the firs stage result). The dependent variable, is the log of total yearly compensation that includes salary, bonus, total value of stock options granted (valued using the standard Black-Scholes formula), total value of restricted stock granted, long-term incentive payouts and other annual compensation; Performance is the natural logarithm shareholders value at fiscal year end ; Import Penetration is Imports divided by Imports plus domestic production at 4 digit SIC, the variable is the mean of the contemporaneous ratio and one forward lag, and it is demeaned with respect to the industry average; Log assets measures firm size; CEO is an indicator for who is the company CEO. See data appendix for further details and sources. 
Table 5: Promotion and Wage Ladders

\begin{tabular}{|c|c|c|c|c|c|c|}
\hline & $\begin{array}{c}\text { Sal.+Bonus } \\
1\end{array}$ & $\begin{array}{c}\text { Total Pay } \\
2\end{array}$ & $\begin{array}{c}\text { Sal+Bonus } \\
3\end{array}$ & $\begin{array}{c}\text { Total comp. } \\
4\end{array}$ & $\begin{array}{c}\text { Total comp. } \\
5\end{array}$ & $\begin{array}{c}\text { Total comp. } \\
6\end{array}$ \\
\hline \multirow[t]{2}{*}{ Import Pen. } & $2.25^{* * *}$ & $1.83^{* * *}$ & $2.20 * * *$ & $1.39^{* *}$ & $11.06^{*}$ & $8.87^{* *}$ \\
\hline & {$[0.37]$} & {$[0.60]$} & {$[0.44]$} & {$[0.62]$} & {$[6.03]$} & {$[4.14]$} \\
\hline \multirow[t]{2}{*}{ Second*Imp.Pen. } & $-0.58^{* *}$ & $-1.62^{* * *}$ & $-0.81^{* *}$ & $-1.39^{* *}$ & -0.77 & $-2.77^{*}$ \\
\hline & {$[0.25]$} & {$[0.44]$} & {$[0.40]$} & {$[0.56]$} & {$[1.72]$} & {$[1.55]$} \\
\hline \multirow[t]{2}{*}{ Third*Imp.Pen } & $-0.69^{* * *}$ & $-1.62 * * *$ & $-1.00^{* *}$ & $-1.06^{*}$ & $-4.73 * * *$ & $-3.87^{* *}$ \\
\hline & {$[0.25]$} & {$[0.46]$} & {$[0.41]$} & {$[0.55]$} & {$[1.59]$} & {$[1.75]$} \\
\hline \multirow[t]{2}{*}{ Fourth*Imp.Pen. } & $-1.00 * * *$ & $-1.10^{* *}$ & $-1.03^{* *}$ & $-1.29 * *$ & -2.11 & -2.66 \\
\hline & {$[0.30]$} & {$[0.48]$} & {$[0.42]$} & {$[0.60]$} & {$[1.74]$} & {$[1.94]$} \\
\hline \multirow[t]{2}{*}{ Fifth*Imp.Pen. } & $-1.34^{* * *}$ & -0.79 & $-1.66^{* * *}$ & -1.01 & $-3.00^{*}$ & $-4.50^{* *}$ \\
\hline & {$[0.44]$} & {$[0.53]$} & {$[0.61]$} & {$[0.66]$} & {$[1.71]$} & {$[1.90]$} \\
\hline \multirow[t]{2}{*}{ Second } & $-0.49 * * *$ & $-0.53^{* * *}$ & $-0.35^{* * *}$ & $-0.24^{* * *}$ & $-0.54^{* * *}$ & $-0.20 * * *$ \\
\hline & {$[0.01]$} & {$[0.01]$} & {$[0.02]$} & {$[0.02]$} & {$[0.02]$} & {$[0.02]$} \\
\hline \multirow[t]{2}{*}{ Third } & $-0.73^{* * *}$ & $-0.81 * * *$ & $-0.50^{* * *}$ & $-0.35^{* * *}$ & $-0.79^{* * *}$ & $-0.28^{* * *}$ \\
\hline & {$[0.01]$} & {$[0.01]$} & {$[0.03]$} & {$[0.02]$} & {$[0.02]$} & {$[0.03]$} \\
\hline \multirow[t]{2}{*}{ Fourth } & $-0.88^{* * *}$ & $-0.97^{* * *}$ & $-0.61 * * *$ & $-0.43^{* * *}$ & $-0.97 * * *$ & $-0.37 * * *$ \\
\hline & {$[0.01]$} & {$[0.01]$} & {$[0.03]$} & {$[0.03]$} & {$[0.02]$} & {$[0.03]$} \\
\hline \multirow[t]{2}{*}{ Fifth } & $-1.02 * * *$ & $-1.11^{* * *}$ & $-0.70^{* * *}$ & $-0.49^{* * *}$ & $-1.09^{* * *}$ & $-0.42^{* * *}$ \\
\hline & {$[0.01]$} & {$[0.01]$} & {$[0.04]$} & {$[0.03]$} & {$[0.02]$} & {$[0.03]$} \\
\hline Year+Industdummies & yes & yes & yes & yes & yes & yes \\
\hline Indiv. Fixed effects & no & no & yes & yes & no & yes \\
\hline IV & no & no & no & no & yes & yes \\
\hline Observations & 23217 & 23222 & 23217 & 23222 & 18251 & 18251 \\
\hline R-squared & 0.7 & 0.64 & 0.88 & 0.84 & 0.63 & 0.67 \\
\hline \multicolumn{7}{|c|}{ Robust standard errors in brackets clustered by firm-year } \\
\hline \multicolumn{7}{|c|}{$\begin{array}{l}\text { Notes: The dependent variable Total Comp., is the log of total yearly compensation that includes salary, bonus, total } \\
\text { value of stock options granted (valued using the standard Black-Scholes formula), total value of restricted stock granted, } \\
\text { long-term incentive payouts and other annual compensation; Sal+bon. is the logarithm of salary plus bonus; Second is a } \\
\text { dummy that records the second most highly paid executive, third is the third most highly paid etc. The base category is the } \\
\text { most highly paid executive in the firm. Import Penetration is Imports divided by Imports plus domestic production at } 4 \\
\text { digit SIC, the variable is demeaned with respect to the industry average; Log assets measures firm size; CEO is an indicator } \\
\text { for who is the company CEO. Column } 3 \text { has industry specific individual fixed effects. Columns } 4 \text { and } 5 \text { are two stage least } \\
\text { squares regressions of table } 3 \text { where Import Penetration and its interaction with the hierarchy dummies are instrumented } \\
\text { with exchange rates and tariffs (see table } 2 \text { for the first stage results). See data appendix for further details and sources. }\end{array}$} \\
\hline
\end{tabular}


Table 6: Talent regressions

\begin{tabular}{|c|c|c|c|c|c|}
\hline & \multicolumn{5}{|c|}{ Non Instrumented } \\
\hline & CEO & 1st & 2nd & $3 \mathrm{rd}$ & 4 th \\
\hline & 1 & 2 & 3 & 4 & 5 \\
\hline \multirow[t]{2}{*}{ Import Pen. } & 0.09 & $0.492^{* * *}$ & $-0.415^{*}$ & $-0.869 * * *$ & $-0.512 * *$ \\
\hline & {$[0.21]$} & {$[0.189]$} & {$[0.227]$} & {$[0.211]$} & {$[0.227]$} \\
\hline \multirow[t]{4}{*}{ Observations } & 4157 & 4876 & 4851 & 4780 & 4578 \\
\hline & \multicolumn{5}{|c|}{ Instrumented } \\
\hline & CEO & $1 \mathrm{st}$ & 2 nd & $3 \mathrm{rd}$ & 4 th \\
\hline & 1 & 2 & 3 & 4 & 5 \\
\hline \multirow[t]{2}{*}{ Import Pen. } & 0.31 & 0.694 & 0.119 & $-1.858 * * *$ & -0.714 \\
\hline & {$[0.51]$} & {$[0.499]$} & {$[0.640]$} & {$[0.594]$} & {$[0.614]$} \\
\hline Observations & 3531 & 3767 & 3752 & 3713 & 3613 \\
\hline Firms & 715 & 730 & 730 & 725 & 715 \\
\hline \multicolumn{6}{|c|}{ Firm fixed effects in all regressions } \\
\hline \multicolumn{6}{|c|}{$*$ significant at $10 \% ; * *$ at $5 \% ; * * *$ at $1 \%$} \\
\hline \multicolumn{6}{|c|}{$\begin{array}{l}\text { Notes: The dependent variable is the estimated fixed effect from a first } \\
\text { stage regression of log of total pay on firm size, hierarchy, year and indus- } \\
\text { try dummies. Import Penetration is defined as in Table } 1 \text {. Each column } \\
\text { represents a different layer of the firm hierarchy. }\end{array}$} \\
\hline
\end{tabular}


Table 7: Survival Analysis: Probability of exit from the firm

\begin{tabular}{|c|c|c|c|c|}
\hline & $\begin{array}{c}\text { Pr. exit } \\
1\end{array}$ & $\begin{array}{c}\text { Pr. exit } \\
2\end{array}$ & $\begin{array}{c}\text { Pr. exit } \\
3\end{array}$ & $\begin{array}{c}\text { Pr. exit } \\
4\end{array}$ \\
\hline \multirow[t]{2}{*}{ Import Pen. } & $5.36^{* * *}$ & 0.71 & 2.22 & -1.96 \\
\hline & {$[1.77]$} & {$[1.65]$} & {$[2.13]$} & {$[1.82]$} \\
\hline \multirow[t]{2}{*}{ ceo } & $-1.08 * * *$ & $-1.07 * * *$ & $-1.08^{* * *}$ & $-1.07^{* * *}$ \\
\hline & {$[0.10]$} & {$[0.10]$} & {$[0.10]$} & {$[0.10]$} \\
\hline \multirow[t]{2}{*}{ Performance } & $-0.21^{* * *}$ & $-0.20^{* * *}$ & $-0.21^{* * *}$ & $-0.20^{* * *}$ \\
\hline & {$[0.04]$} & {$[0.04]$} & {$[0.04]$} & {$[0.04]$} \\
\hline \multirow[t]{2}{*}{$\ln ($ assets $)$} & $0.22^{* * *}$ & $0.22^{* * *}$ & $0.22^{* * *}$ & $0.22^{* * *}$ \\
\hline & {$[0.04]$} & {$[0.04]$} & {$[0.04]$} & {$[0.04]$} \\
\hline \multirow[t]{2}{*}{ Baseline Hazard: $\ln (\mathrm{t})$} & 0.04 & 0.02 & 0.03 & 0.02 \\
\hline & {$[0.04]$} & {$[0.04]$} & {$[0.04]$} & {$[0.04]$} \\
\hline Year dummies & no & yes & no & yes \\
\hline Instrimented imp.pen. & no & no & yes & yes \\
\hline Observations & 6193 & 6146 & 6193 & 6146 \\
\hline \multicolumn{5}{|c|}{ Standard errors in brackets } \\
\hline \multicolumn{5}{|c|}{$*$ significant at $10 \% ; * *$ at $5 \% ; * * *$ at $1 \%$} \\
\hline \multicolumn{5}{|c|}{$\begin{array}{l}\text { Notes: Estimates a logistic hazard model of the probability of exiting } \\
\text { the firm. The baseline hazard is defined as the logarithm of spell } \\
\text { duration and } 11 \text { other variables are defined as in table } 1 \text {. Columns } 3 \\
\text { and } 4 \text { use predicted import penetration using our instruments instead } \\
\text { of the raw value in Columns } 1 \text { and } 2 \text {. See data appendix for further } \\
\text { details and sources. }\end{array}$} \\
\hline
\end{tabular}


Figure 1: Import Penetration (deviation from mean) in 3 selected industries

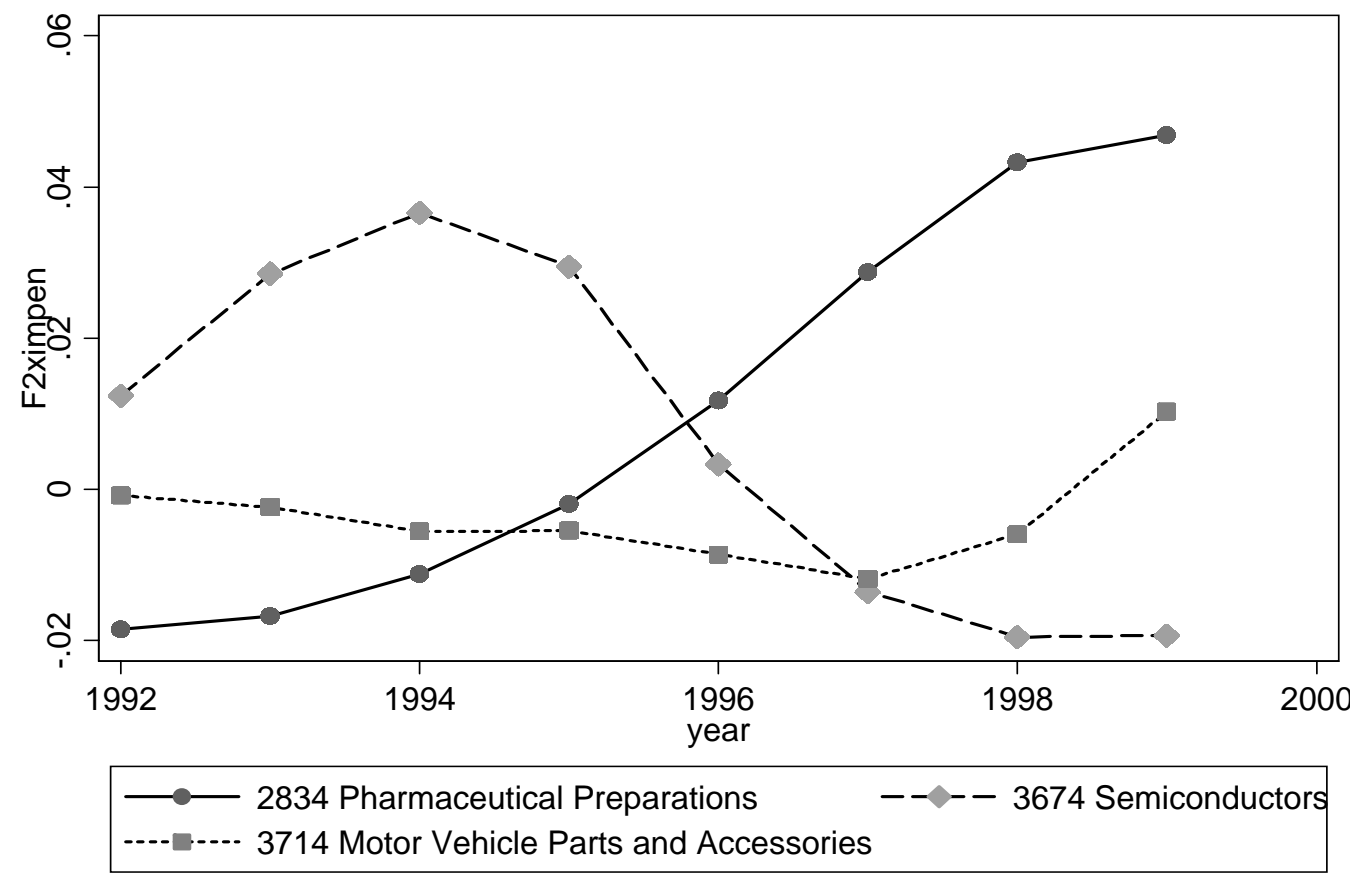


Figure 2: Kaplan-Meier Survival Estimates, by import penetration

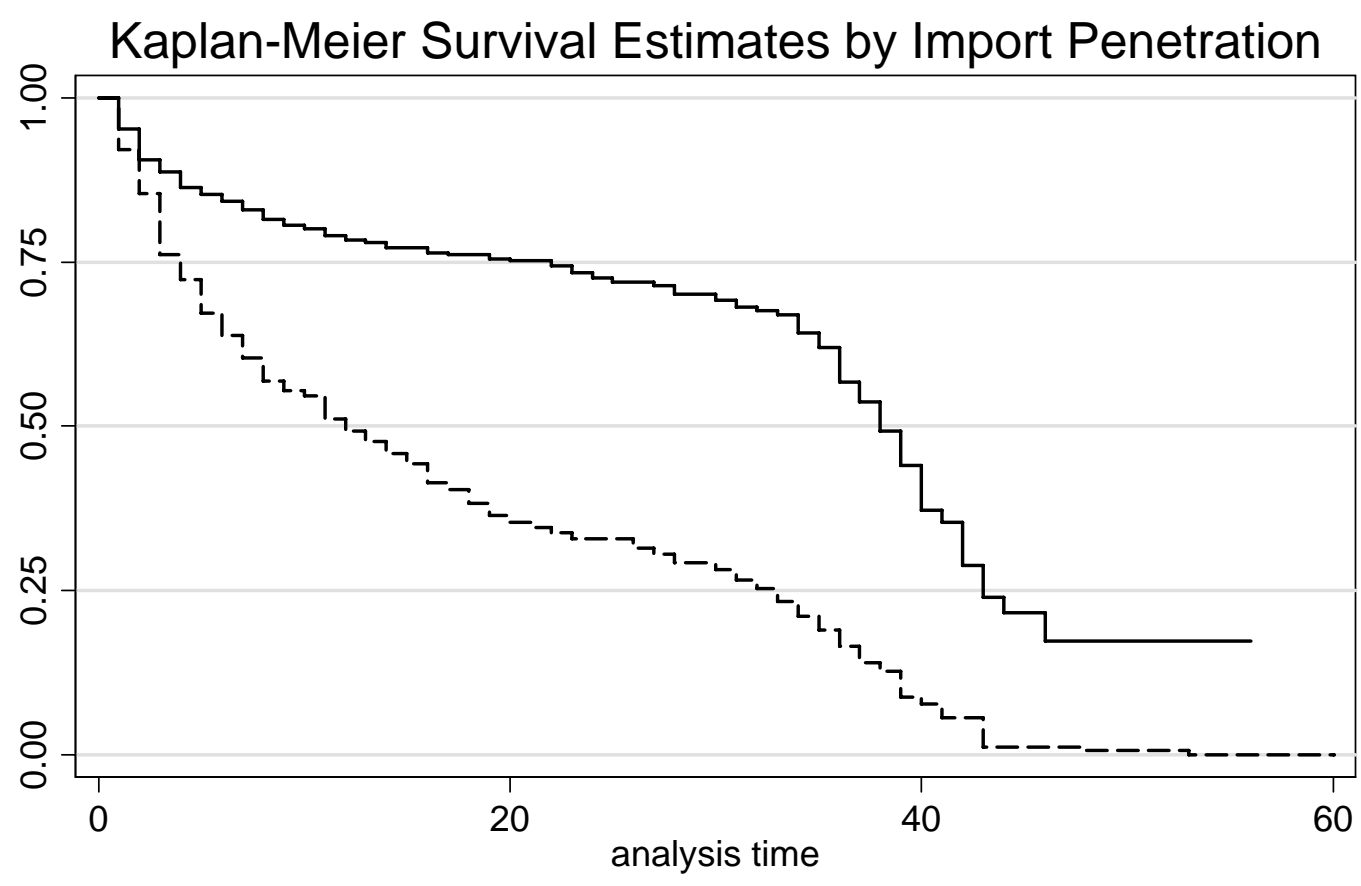

Below Average Import Pen. - - - - Above Average Import Pen. 
Figure 3: Kaplan-Meier Survival Estimates, by predicted (IV) import penetration

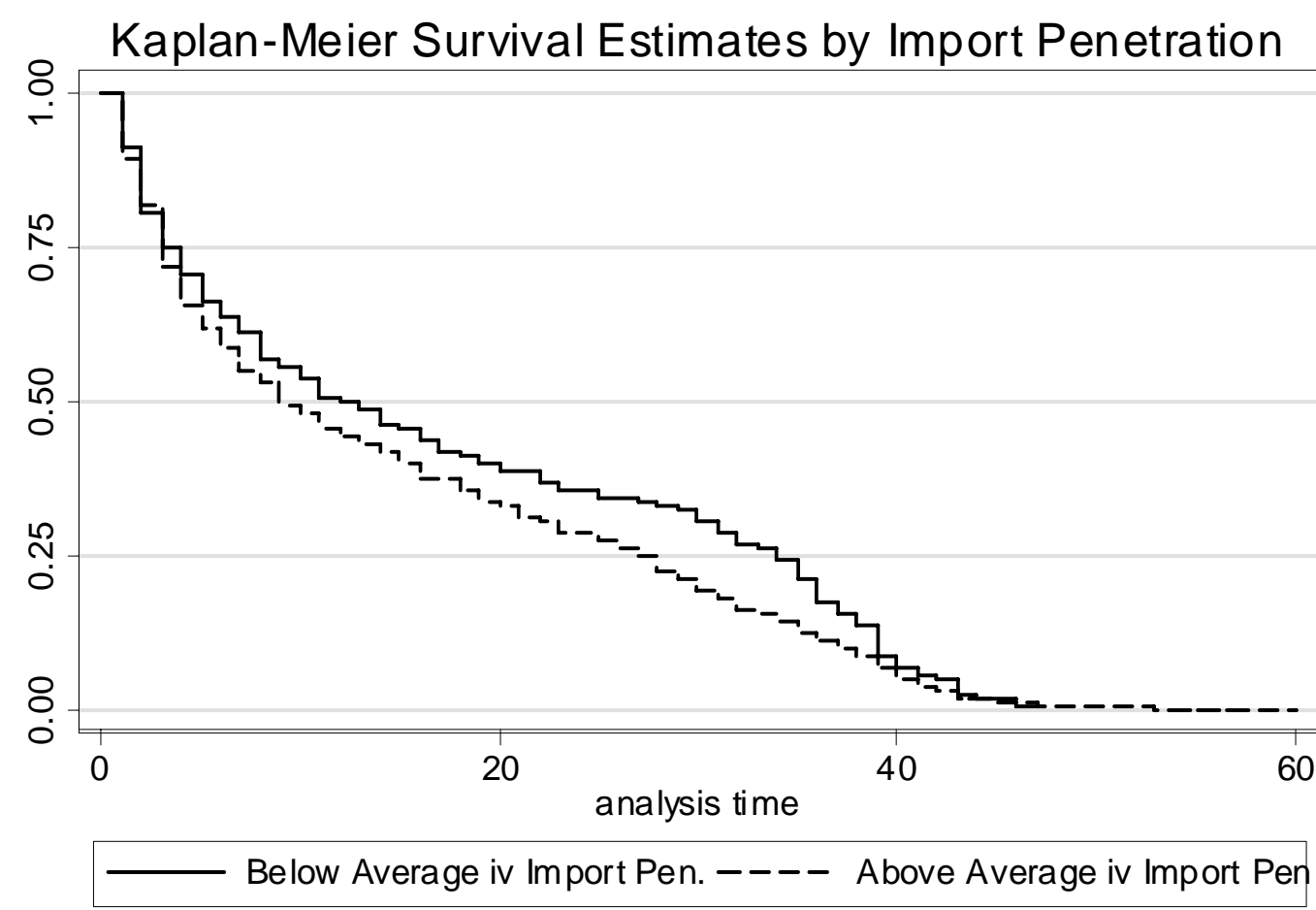

